\title{
THE Migration OF THE LesSER KeStrel Falco naumanni In EASTERN EUROPE - A RINGING RECOVERY AND DIRECT OBSERVATION APPROACH
}

\section{Selitev južnih postovk Falco naumanni v vzhodni Evropi - pristop z analizo obročkovalskih najdb in neposrednim opazovanjem}

\author{
Anastasios Bounas ${ }^{1}$, Michele Panuccio ${ }^{2}$, Angelos Evangelidis ${ }^{3}$, Konstantinos Sotiropoulos ${ }^{1}$, \\ CHRISTOS BARBOUTIS ${ }^{3}$ \\ 1 Molecular Ecology and Conservation Genetics Lab, Department of Biological Applications and Technology, University \\ of Ioannina, 45110, Ioannina, Greece, e-mail: abounas@cc.uoi.gr, ksotirop@cc.uoi.gr \\ 2 MEDRAPTORS (Mediterranean Raptor Migration Network), via Mario Fioretti 18, 00152 Rome, Italy, e-mail: \\ panucciomichele@gmail.com \\ 3 Antikythira Bird Observatory, Hellenic Ornithological Society / BirdLife Greece, Themistokleous 80, GR-10681 Athens, \\ Greece,e-mail: evangelidis@ornithologiki.gr,cbarboutis@ornithologiki.gr
}

We examined ringing recovery data of the Lesser Kestrel Falco naumanni in order to analyse its migration patterns and philopatry rates in Eastern Europe. In addition, we extracted counts of migrating birds from online databases and studied the use of the flyway as well as the phenology of both spring and autumn migrations through Greece. Birds appeared to migrate in the same mean direction in spring and autumn through the Italian and Balkan Peninsulas. During spring, movements took place on a broad front from March until midMay with a peak in mid-April; in autumn, birds migrated through Greece on a narrower front from early August to early October, with most of individuals passing through Greece in mid-September. Finally, philopatry rates were higher for adults, while juvenile birds dispersed more often and at longer distances, up to $974 \mathrm{~km}$ away. Our results on migration patterns generally agree with those in other studies, but we found some evidence of long-distance premigratory movements towards mainland Greece that could also shape the narrower front migration in autumn. In addition, long distance dispersal movements of juveniles in southeastern Europe, where Lesser Kestrel populations show a fragmented distribution, could facilitate gene flow between populations, thus avoiding the negative effects of mating with genetically similar individuals.

Keywords: Lesser Kestrel, Falco naumanni, Greece, bird migration, ringing recoveries

Ključne besede: južna postovka, Falco naumanni, Grčija, selitev ptic, obročkovalske najdbe

\section{Introduction}

A vast number of birds, including many raptors, move between the western Palearctic and Africa (BERTHOLD 200I). Birds migrating through Greece face a large ecological barrier, the Mediterranean Sea, the shortest distance between Greece (Crete Island) and Africa being approximately $280 \mathrm{~km}$. The length of the barrier leads the main flyways of several species to converge through the Balkans and in the Eastern Mediterranean
(Panuccio et al. 2012, Schindler et al. 2015) with only a few raptor species attempting the long water crossing between Greece and Africa (LuCIA et al. $20 \mathrm{I}$ I, Panuccio et al. 2013).

Bird ringing has provided undeniable insight into the biology of birds over the years, especially on their movements and migration routes (BAIRLEIN 200I). The increasing number of ringing schemes in Europe provides useful data and the process of handling large datasets has been facilitated in the last 
decades (FRANSSON 200I). As a result, bird ringing is widely used in many studies concerning the ecology, behaviour, migration and conservation of bird populations (BAILLIE 200I). In addition, emerging citizen science platforms can provide a wealth of information that can be used in ecological and conservation studies, including the study of migration flyways and general phenology (DiCKInson et al. 20IO, HURLBERT \& LiANG 2OI2).

The Lesser Kestrel Falco naumanni is a small migratory falcon that breeds in southern Europe and winters in sub-Saharan Africa (CRAMP \& Simmons 1980). The species disperses from the breeding grounds in late July and August, and migrates on a broad front from August to October. In spring it migrates in small groups, reaching southern Europe during March - April (Forsman 1999). The species regularly crosses the Mediterranean Sea during both autumn and spring migrations (MEYER et al. 2003). Additionally, the species is highly philopatric, with the majority of first time breeders returning within $10 \mathrm{~km}$ from their natal colony in Spain (NEGRO et al.
1997, SERRANO et al. 2003). However, there is evidence of long-distance dispersal events (PRUGNOLLE et al. 2003) and the importance of such movements is reflected in the low genetic differentiation between geographically distant populations (ALCAIDE et al. 2009).

In the Balkans and Central Europe, the species underwent a decline that led to the extinction of several national populations (e.g. in Bulgaria, Serbia, Slovenia, and Ukraine) and also of several colonies in all other countries (INIGO \& BAROV 2OIO). This process resulted in a fragmented distribution of the species in the Balkan Peninsula. Currently, Greece is still among the most populated areas in southern Europe, hosting $2-3 \%$ of the European population with approximately 2,600-3,300 pairs in 140 recorded breeding colonies, most of them concentrated in the Thessaly region, Central Greece (Legakis \& MARAgou 2009).

In this study we utilised the recoveries of Lesser Kestrels ringed in Eastern Europe, data from two bird observation databases, and data from raptor counts in Greece in order to study the phenology, migration

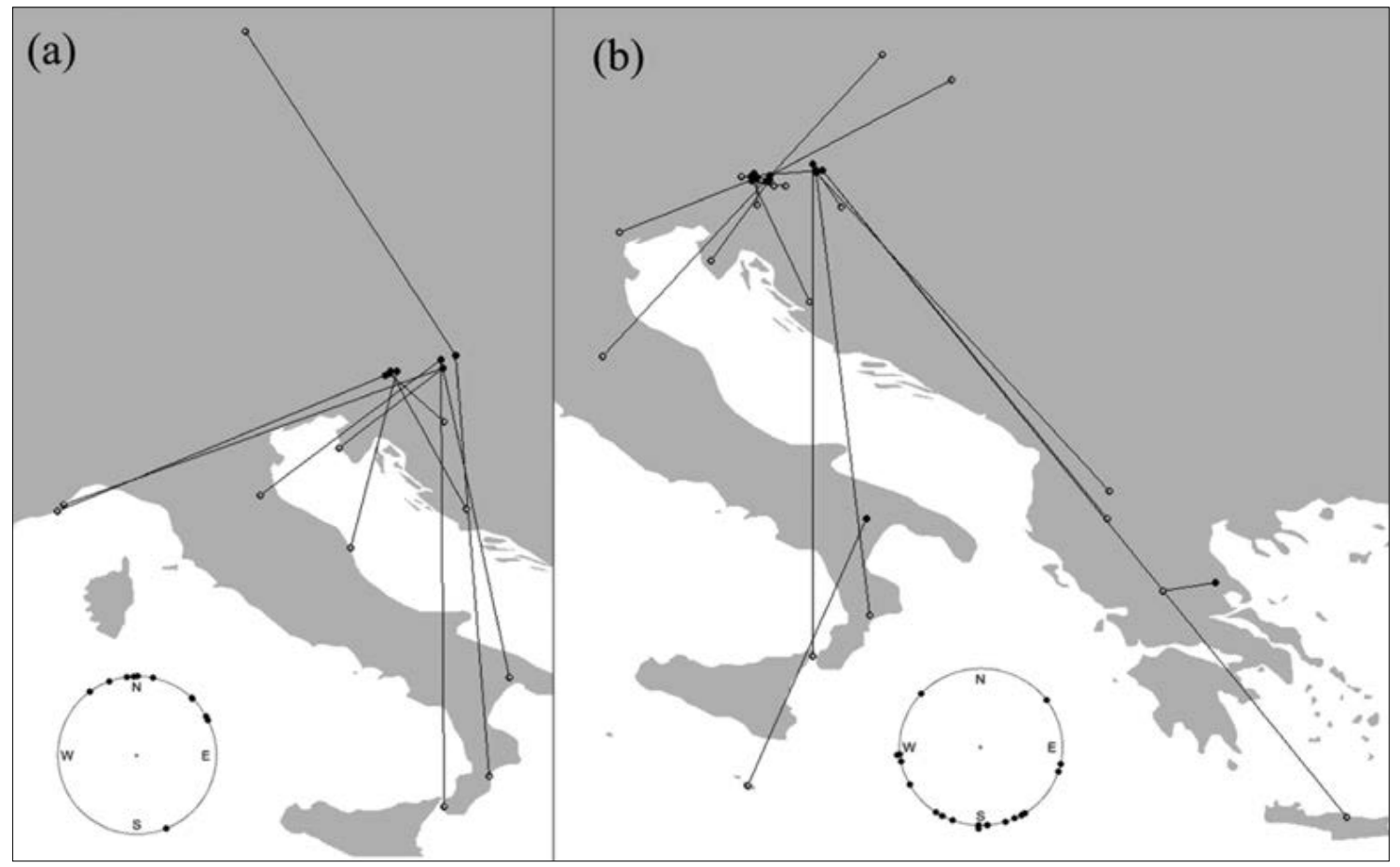

Figure 1: Recoveries of Lesser Kestrels Falco naumanni ringed between 1947 and 2002 and their movement directions during (a) Spring migration (February-April, $n=11$ recoveries) and (b) Autumn migration (August-October, $n=19$ recoveries). Filled black and open dots represent ringing and recovery locations, respectively. Lines connect ringing with recovery locations.

Slika 1: Najdbe južnih postovk Falco naumanni, obročkanih med letoma 1947 in 2002, in smer premikov med (a) spomladansko selitvijo (februar-april, $n=11$ najdb) in (b) jesensko selitvijo (avgust-oktober, $n=19$ najdb). Polni krožci ponazarjajo kraj obročkanja, prazni pa kraj najdbe. Črte povezujejo oba kraja. 
patterns and flyways over Greece and Eastern Europe. We also provided an estimate of philopatry rates using ringing recovery data. These analyses are aimed to improve the knowledge of the migration behaviour in the region as well as the potential connectivity of populations through breeding and natal dispersal movements. Such information can have an impact on future conservation actions and genetic studies in the region.

\section{Methods}

For the migration pattern analysis we used data from 30 individuals ringed and recovered between 1947 and 2002 across 10 countries (Albania, Austria, Croatia, Czech Republic, The Former Yugoslav Republic of Macedonia, Germany, Greece, Italy, Malta and Slovenia). 19 of these individuals were recovered during autumn migration, and 11 recoveries were used for spring migration patterns. Regarding philopatry, our dataset consists of 22 recovered juveniles and 16 adult birds originating from Austria, France, Greece, Italy and Poland.

These observations were extracted from a total of 966 recoveries of ringed Lesser Kestrels provided by the EURING Data Bank (DU FeU et al. 2009) and spanning 79 years from 1934 to 2013 . For our migration pattern analyses recoveries from birds ringed in Spain and France were discarded, since we were interested in the eastern European range of the species, thus resulting in 77 recoveries relevant for the region. These 77 recoveries were subsequently filtered in order to study the migration patterns of the species. We included birds that had a recovery date accurate to within two weeks at the most and ringing and recovery coordinates that were accurate within $50 \mathrm{~km}$. For autumn migration we used records of birds ringed in the breeding season between April and July and recovered between late August and October in the same or subsequent years. We excluded recoveries with less than $30 \mathrm{~km}$ between ringing and recovery sites in order to eliminate local pre-migration gatherings but to keep possible longdistance pre-migratory movements. Spring migration movements were considered from records of birds ringed between April and July and recovered between February and April of the same or consecutive years after eliminating observations where recovery distance was less than $50 \mathrm{~km}$ in order to avoid bias from birds that could have dispersed and bred in nearby colonies. All data manipulation and analyses were performed in $\mathrm{R}$ 3.2.2 ( $\mathrm{R}$ CORE TEAM 2015) using the package "birdring" (KorNer-NIEvergelt \& ROBINSON 20I4). Direction and distances were provided with the EURING dataset. Movement directions were plotted and analysed using the R package "circular" (AgOSTINELli \& LUND 20I I). In order to visualize the inverse movements in spring migration we transformed the directions by adding $180^{\circ}$ to the calculated values. The non-parametric Mardia-Watson-Wheeler test was used to test for differences in the mean or variance of migration directions between spring and autumn. In order to examine whether Lesser Kestrels migrate on

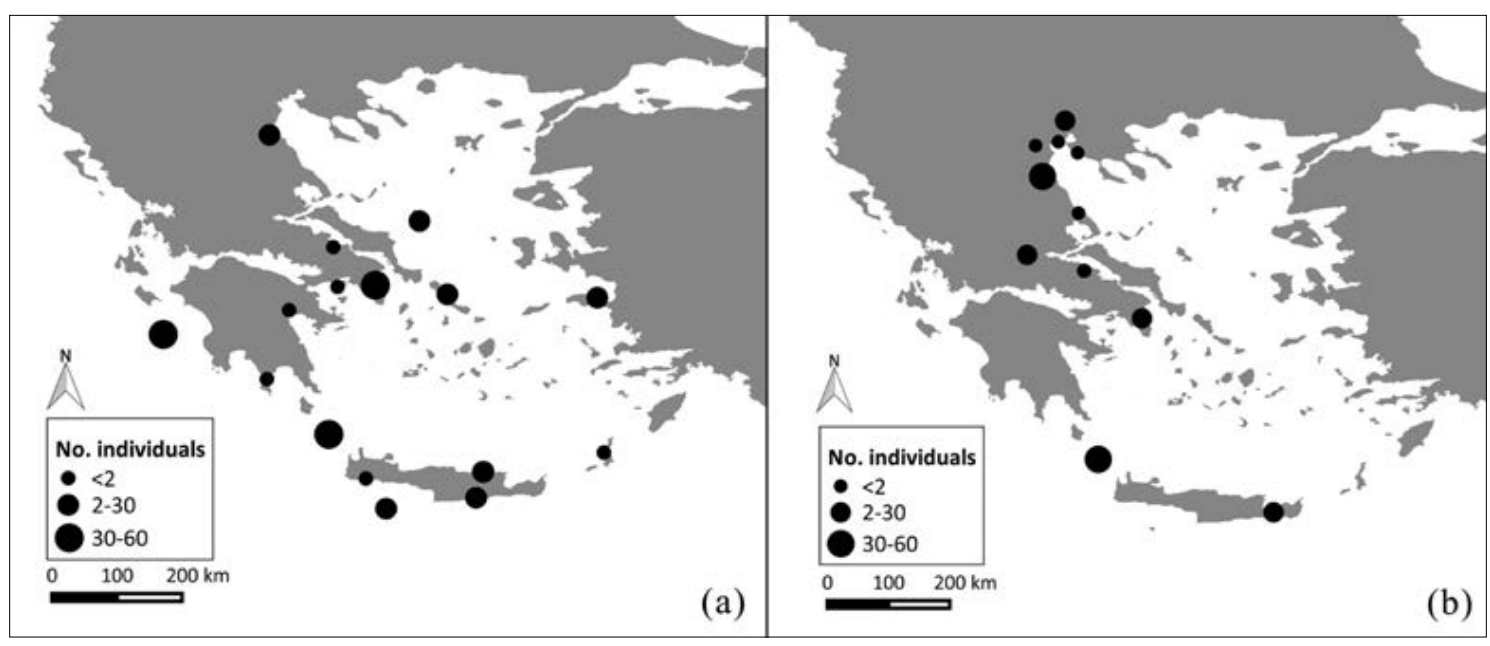

Figure 2: Observations of Lesser Kestrels Falco naumanni migrating over Greece from 1958 to 2013. (a) Spring migration, (b) Autumn migration.

Slika 2: Opazovanje južnih postovk Falco naumanni selečih se čez Grčijo med letoma 1958 in 2013. (a) spomladanska selitev, (b) jesenska selitev. 
a broad front or through specific bottleneck areas over Greece, we extracted observations of migrating birds in spring (February to May) and autumn (August to October), during the 2001-2013 period from Ornithotopos database (HELLENIC ORNITHOLOGICAL SocIETY 2009), data supplied by Observation.org (https://observation.org), observations reported in the literature (Vaughan 1960, Panuccio et al. 20I I) as well as observations obtained from personal communications. We considered these observations to be of migrating birds since they were made far from breeding colonies of the species in Greece. In addition, these birds were observed in active migration during the migratory periods mentioned above and were moving in the expected direction of migration. Maps were designed with Qgis (v. 2.12.3.). The description of the migratory phenology of the species is based on raptor count data through the 2006-2015 period, from Antikythira Bird Observatory, Spata (Attica) and Olympus Mountain for the autumn migration, and Spata (Attica) for the spring migration. Values are presented as median and interquartile range. Plots were prepared using the R package "ggplot2" (WICKHAM \& CHANG 2009).

We examined the philopatry of Lesser Kestrels in two age classes: birds ringed as fledglings or juveniles that returned to breed after one or subsequent years and birds ringed after their first year (subadults and adults) returning to breed after one or more years (natal and breeding philopatry, respectively). We considered birds to be dispersed if they did not return to breed around their natal colony $(\leq 1 \mathrm{~km})$. We filtered the EURING data taking into account the ringing location (birds ringed in Spain were not included), date of ringing and recovery (defining the breeding season from April to June), accuracy of coordinates (accurate within $10 \mathrm{~km}$ ) and condition and circumstances of recovered birds (since a part of recoveries includes dead birds, we eliminated observations that did not have information on how recently the birds had died). We used data from birds ringed in France in this analysis in order to examine possible eastward dispersal. Recoveries that included recently dead birds in a radius of $5 \mathrm{~km}$ from the place where they were ringed were double checked on the map and placed in the nearest breeding site, since the distance may indicate a feeding movement of a bird when it died. Additionally, we included eight recoveries of marked individuals from all over Greece that were a part of an ongoing genetic sampling project.

\section{Results}

The mapping of ringing recoveries shows movements of birds through both the Italian and Balkan Peninsulas in autumn, while in spring migrating individuals were only recovered through the Italian Peninsula (Figure 1). Some birds moved in northeasterly or westerly directions in early August, probably indicating some long distance premigratory movements. The mean directions for migrating birds in autumn and spring were $185.5^{\circ} \pm 31^{\circ}(95 \% \mathrm{CI})$ and $28.2^{\circ} \pm 36.5^{\circ}$ ( $95 \% \mathrm{CI})$, respectively. No significant differences were found in the mean migration axis or in the variance between spring and autumn migration (Mardia- (a)

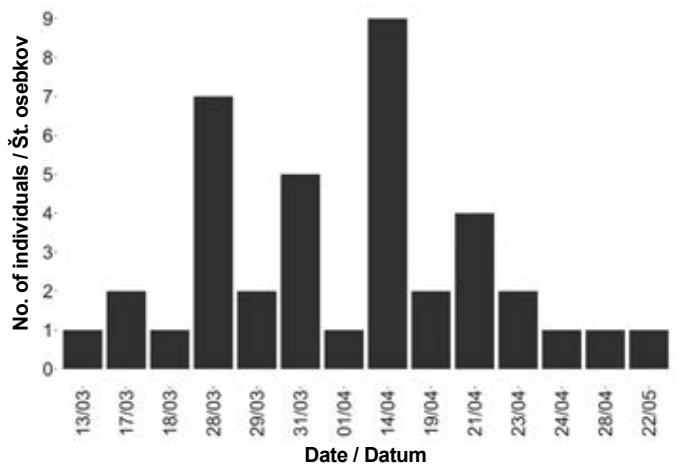

(b)

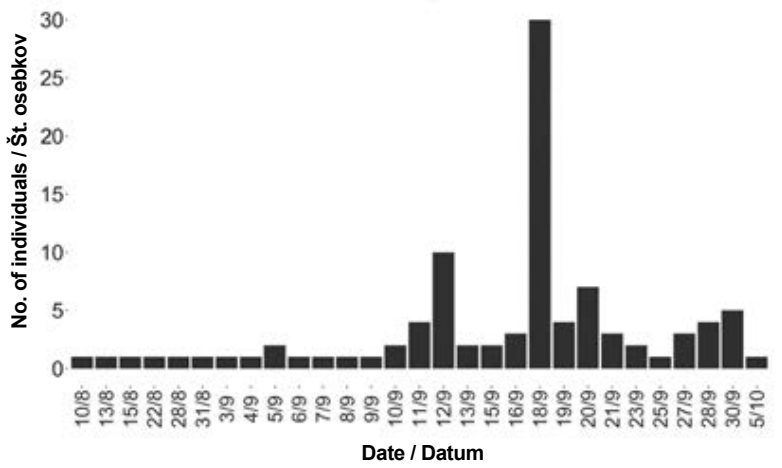

Figure 3: Phenology of individuals migrating through Greece between the years 2006 and 2015. (a) Spring migration, (b) Autumn migration.

Slika 3: Fenologija osebkov, selečih se skozi Grčijo, med letoma 2006 in 2015. (a) spomladanska selitev, (b) jesenska selitev. 
Watson-Wheeler test: $\mathrm{W}=1.4, \mathrm{df}=2, P=0.49$ ). Observations were gathered of 181 migrating Lesser Kestrels from 13 different locations during spring and of 115 individuals from 10 locations in autumn. Birds appear to migrate on a broad front, especially in spring when birds were recorded in both western and eastern Greece as well as through the Aegean Sea on various islands (Figure 2a). Migration in autumn appears to take place on a narrower front, with most birds flying over mainland Greece, Antikythira Island and Crete (Figure 2b). From the standardized counts, spring migration over Greece occurs from March till mid-May with a peak in mid-April $(\mathrm{n}=39$, median $=14$ April, interquartile range: $28 \mathrm{Mar}$ to $19 \mathrm{Apr}$; Figure 3a). Autumn migration extends from early August to early October, peaking in mid-September $(\mathrm{n}=101$, median $=18 \mathrm{Sep}$, interquartile range: 12 to $20 \mathrm{Sep}$; Figure $3 \mathrm{~b}$ ).

Of the 22 juveniles recovered, 15 showed natal philopatry and 7 dispersed. A long-distance dispersal was observed to the west. 2 birds ringed in Austria were recovered breeding in Italy (974 km and $684 \mathrm{~km}$ away) and 2 birds ringed in France were recovered breeding in Spain (464 km and $369 \mathrm{~km}$ away). The remainder dispersed closer to their natal colonies $(23 \mathrm{~km}, 28 \mathrm{~km}$ and $60 \mathrm{~km}$ ). Of the 16 adults, only one dispersed at a distance of $17 \mathrm{~km}$, while 15 returned to breed on the same grounds. Thus, philopatry rates for adults and for juveniles differed significantly $\left(\chi^{2}=3.643, \mathrm{df}=1\right.$, $P<0.05)$.

\section{Discussion}

\subsection{Migration patterns}

A combination of available ringing recovery data and direct observations was used in order to describe the migration patterns of Lesser Kestrels in Eastern Europe. No differences were found in the mean migration axis between autumn and spring, but birds appear to migrate through the region on a narrower front during autumn. In addition, the range of the migration period was defined as well as peak days of the species' migration in autumn and spring.

No evidence was found that birds used different migration routes in spring and autumn (loop migration) in the region. In autumn, birds migrated through both the Italian and Balkan Peninsulas, and some important movements were identified during this period. In particular, a juvenile ringed in Austria was recovered after 54 days $793 \mathrm{~km}$ away in Albania in mid-August, an adult female ringed in Austria was recovered in the Former Yugoslav Republic of Macedonia (FYROM) on 20 July of the same year having moved $750 \mathrm{~km}$, and a juvenile ringed in central Greece moved to the west and was recovered in mid-July $100 \mathrm{~km}$ away from its natal colony. Since the dates of recoveries are too early for full migration and the recovery sites host well-known large premigratory roosts (THORPE \& HOLMES 1936, Minias et al. 2009, BounAs et al. 2016), we suggest that these individual-specific movements reflect the gathering of birds at pre-migratory sites. Such movements (even some northward ones) have already been reported in studies from the Iberian Peninsula (Bustamante \& Negro i994, Olea 200i, Catry et al. 20 i i).

Counts of migrating birds in Greece confirmed the broad-front migration strategy that is known for the species in other areas (MEYER et al. 2003, AlON et al. 2004). Although in spring birds migrated all across Greece, in autumn birds appeared to migrate on a narrower front. This result is in agreement with counts reported in the Central Mediterranean area. In Italy, Lesser Kestrels are commonly observed during spring in small numbers at different watch-sites, also on the small islands of the Tyrrhenian Sea, and along the Adriatic coast en route for the Balkan Peninsula (Panuccio et al. 2004, Premuda et al. 2004). On the other hand, in autumn, observations of actively migrating Lesser Kestrels are concentrated at the Strait of Messina where up to 753 individuals per season were estimated (Agostini et al. 2015). Part of the same migratory flow is subsequently detected over Malta en route to Libya (SAmmut \& Bonavia 2004). Conversely, birds tracked from Spain migrated on a broad-front in autumn and concentrated through Gibraltar in spring (Limiñana et al. 2012). The apparent narrower front during autumn migration in Greece could again be a result of the premigratory gatherings in the Balkans, with birds concentrating in areas of mainland Greece and then converging along the "mainland GreeceAntikythira-Crete" flyway.

Estimation of the migration period and peak of the Lesser Kestrel in the region generally conformed to studies in the Italian Peninsula, where the spring migration begins in March, peaks from early to midApril with some variation of the peaking date between years (CORSO 200I, Giordano et al. 2008, PREMUda et al. 2008) and lasts till early May. In the Iberian Peninsula birds appear to arrive earlier, migrating from the first half of February till mid-April (RodRIguez et al. 2009, CATRY et al. 20I I). Late migrants observed from late April to mid-May could include nonbreeding individuals as well as birds reaching their northern breeding grounds where breeding occurs later (Mikulić et al. 2013). In autumn, Lesser Kestrels migrated over Greece from August to early October, peaking in mid-September, a little earlier than in Spain 
(RodrigueZ et al. 2009, Limiñana et al. 2012) but in the same period, with the closest migration routes in central Mediterranean (GAlea \& MASSa 1985) and western Black Sea (Michev et al. 20 I I).

Analyses based on ringing recovery data can be biased due to the low recovery rates and irregular spatial distribution (PerdecK 1977, STRANDBERG et al. 2009). Thus, they do not provide a complete picture of bird migration but rather a general view of migration patterns. In our study, we had relatively few ringing recoveries so we used observations and counts of migrating birds in order to describe the species migration patterns in the region. Ringing recoveries were used to provide supplementary information on the long-distance movements of individuals. Despite that, information on migration of the species in the region can still be relevant for conservation actions.

\subsection{Philopatry}

According to our results, philopatry is higher in adult birds than in juveniles. Juveniles that dispersed did so on long distances, while adults showed much higher fidelity on their breeding grounds. There is evidence that the probability of dispersal decreases with age (Serrano et al. 200I, Calabuig et al. 2008) while such long distance dispersal movements exist but could be underestimated (Prugnolle et al. 2003). A reason for that could be that estimating philopatry rates from ringing recovery data has its drawbacks since ringing intensity varies with locations and longdistance dispersal movements of individuals could be difficult to detect. Various reasons have been proposed for such dispersive behaviour in juvenile birds such as the increase of population density that leads to an increased dispersal (NEgRo et al. 1997). Moreover, high natal dispersal of juveniles (83\%) has been observed in more isolated populations (SERRANO et al. 2003). In Southeastern Europe, where Lesser Kestrel populations show a fragmented distribution, such dispersal movements could facilitate gene flow between populations, thus avoiding the negative effects of mating with genetically similar individuals.

\section{Acknowledgements}

We are very grateful to all the people that shared their observations on the online platforms used in this study. We also thank Chris du Feu (EURING), Danae Portolou and Nikos Tsiopelas (Hellenic Ornithological Society), Hisko de Vries (observation.org) and Giannis Vlatsiotis and Nikos Fokas (conducting counts at Spata, Attica) for their cooperation on providing the data. We thank Thord Fransson, Giorgos Karris, Stavros Xirouchakis and Elisabeth Navarrete who shared their unpublished data with us. We appreciate the constructive comments by Victoria Saravia, Jurij Hanžel and two anonymous reviewers on an earlier draft of this paper. This is contribution No. 21 from Antikythira Bird Observatory, a project run by the Hellenic Ornithological Society. The Antikythira Bird Observatory is funded by A. G. and A. P. Leventis Foundation.

\section{Povzetek}

$\mathrm{Za}$ analizo selitvenih vzorcev in stopnje filopatrije južne postovke Falco naumanni v vzhodni Evropi smo preučili podatke o obročkovalskih najdbah. Dodatno smo iz spletnih podatkovnih baz pridobili še podatke o opazovanjih selečih se ptic, da bi preučili selitvene poti in fenologijo spomladanske ter jesenske selitve skozi Grčijo. Ptice so se tako spomladi kot jeseni selile $\mathrm{v}$ isti povprečni smeri vzdolž Apeninskega in Balkanskega polotoka. Spomladi so se selile v široki fronti med marcem in majem $\mathrm{z}$ viškom sredi aprila, jeseni pa je bila selitev v Grčiji prostorsko bolj zgoščena med začetkom avgusta in začetkom oktobra $\mathrm{z}$ viškom sredi septembra. Stopnja filopatrije je bila večja pri odraslih osebkih, medtem ko je bila pri mladih osebkih disperzija pogostejša in daljša, do $974 \mathrm{~km}$. Naše ugotovitve o selitvenih vzorcih se v splošnem ujemajo z drugimi raziskavami, vendar smo opazili daljše predselitvene premike proti celinski Grčiji, ki bi lahko bili vzrok za prostorsko bolj zgoščeno jesensko selitev. V jugovzhodni Evropi, kjer so populacije južnih postovk daleč vsaksebi, bi bili dolgi disperzijski premiki mladih osebkov pomembni za genski pretok med populacijami, ki bi preprečil negativne učinke parjenja med sorodnimi osebki.

\section{References}

Agostinelli C., Lund U. (2011): R package circular: Circular Statistics (version 0.4-3). - CA Department of Environmental Sciences, Informatics and Statistics, Ca'Foscari University, Venice, Italy. UL: Department of Statistics, California Polytechnic State University, San Luis Obispo, California, USA.

Agostini N., Scuderi A., Chiatante G., Bogliani G., PANuccio M. (2015). Factors affecting the visible southbound migration of raptors approaching a water surface. - Italian Journal of Zoology 82 (2): 186-193.

Alcaide M., Serrano D., Tella J. L., Negro J. J. (2009): Strong philopatry derived from capture-recapture records does not lead to fine-scale genetic differentiation in Lesser Kestrels. - Journal of Animal Ecology 78: 468475 . 
Alon D., Granit B., Shamoun-Baranes J., Leshem Y., Kirwan G. M., Shirihai H. (2004): Soaring-bird migration over northern Israel in autumn. - British Birds 97 (4): 160-182.

BAILlIE S. (200I): The contribution of ringing to the conservation and management of bird populations: a review. - Ardea 89 (1): 167-184.

BAIRLEIN F. (200I): Results of bird ringing in the study of migration routes and behaviour. - Ardea 89 (1): 7-19.

BERTHOLD P. (200I): Bird migration: a general survey. Oxford University Press, Oxford.

Bounas A., Tsiakiris R., Vlachopoulos K., Bukas N., STARA K., Sotiropoulos K. (2016): Large premigratory roost of Lesser Kestrels (Falco naumanni) in Ioannina city, Greece: trends, roost characteristics and implications for conservation. - Journal of Raptor Research 50 (4): 416-421.

Bustamante J., Negro J. J. (I 994): The post-fledging dependence period of the Lesser Kestrel (Falco naumanni) in southwestern Spain. - Journal of Raptor Research 28 (3): $158-163$

Calabuig G., Ortego J. N., Cordero P. J., Aparicio J. M. (2008): Causes, consequences and mechanisms of breeding dispersal in the colonial lesser kestrel, Falco naumanni. - Animal behaviour 76 (6): 1989-1996.

Catry I., Dias M. P., Catry T., Afanasyev V., Fox J., Franco A. M. A., Sutherland W. J. (20 I I): Individual variation in migratory movements and winter behaviour of Iberian Lesser Kestrels Falco naumanni revealed by geolocators. - Ibis 153 (1): 154-164.

Corso A. (200I): Raptor migration across the Strait of Messina, southern Italy. - British Birds 94 (4): 196-202.

Cramp S., Simmons K. (1980): Birds of the Western Palearctic, Vol. 2. - Oxford University Press, Oxford.

Dickinson J. L., Zuckerberg B., Bonter D. N. (2010): Citizen science as an ecological research tool: challenges and benefits. - Annual review of ecology, evolution and systematics 41: 149-172.

du Feu C. R., Joys A. C., Clark J. A., Fiedler W., Downie I. S., van Noordwijk A. J., Spina F., WassenaAR R., BAILlIE S.R. (2009): EURING Data Bank geographical index 2009. - [http://www.euring.org/edb].

ForSMAN D. (1999): The raptors of Europe and the Middle East: a handbook of field identification. - T \& AD Poyser, London.

FransSON T. (2001): To analyse ringing recoveries in a national atlas - examples from the Swedish project. Ardea 89 (1): 21-30.

Galea C., Massa B. (1985): Notes on the raptor migration across the central Mediterranean. - Conservation Studies on Raptors, ICBP Technical Publication 5: 257-261.

Giordano A., Ricciardi D., Chiofalo G., Ramirez J., Guerrero M., Vella R., Fiott J. P., Vanni L., Macumelli E., Cutini S. (2008): The spring migration of the Lesser Kestrel Falco naumanni on the Straits of Messina, data from 1991 to 2008. pp. 155-158. In: Actes du VIIe Congrés International sur le Faucon crécerellette. - Almendralejo, Spain.

Hellenic Ornithological Society. (2009): Data extracted from Ornithotopos http://www.worldbirds. org/greece on 21 January 2016. HOS, Athens.
Hurlbert A. H., LiAng Z. (2OI 2): Spatiotemporal variation in avian migration phenology: citizen science reveals effects of climate change. - PloS ONE 7 (2): e31662.

IÑIgo A., Barov B. (2010). Action Plan for the Lesser Kestrel (Falco naumanni) in the European Union. pp. 55. Birdlife International for the European Commission.

KORNER-NiEVERGELT F., RobinSON R.A. (2014): Introducing the R-package 'birdring'. - Ringing \& Migration 29 (1): 51-61.

Legakis A., Maragou P. (2009): The Red Book of Threatened Animals of Greece. - Hellenic Zoological Society, Athens, Greece.

Mikulić K., Budinski I., Čulina A., JuRinović L., Lucić V. (2013): The return of the Lesser Kestrel (Falco naumanni) as a breeding bird to Croatia. - Acrocephalus 34 (156/157): 71-74.

Limiñana R., Romero M., Mellone U., Urios V. (2012): Mapping the migratory routes and wintering areas of Lesser Kestrels Falco naumanni: new insights from satellite telemetry. - Ibis 154: 389-399.

Lucia G., Agostini N., Panuccio M., Mellone U., Chiatante G., Tarini D., Evangelidis A. (201 I): Raptor migration at Antikythira, in southern Greece. British Birds 104 (5): 266.

Meyer S. K., SpaAr R., Bruderer B. (2003): Sea crossing behaviour of falcons and harriers at the southern Mediterranean coast of Spain. - Avian Science 3 (2/3): 153-162.

Michev T., Profirov L., Nyagolov K., Dimitrov M (20I I): The autumn migration of soaring birds at Bourgas Bay, Bulgaria. - British Birds 104 (1): 16-37.

Minias P., Kaczmarek K., Piasecka A., Kuncewicz M. (2009): Large Roost of Lesser Kestrels in Southeastern Albania. - Journal of Raptor Research 43 (2): 166-167.

Negro J. J., Hiraldo F., Donázar J. A. (1997): Causes of natal dispersal in the lesser kestrel: inbreeding avoidance or resource competition? - Journal of Animal Ecology 66: 640-648.

Olea P. (200I): Postfledging dispersal in the endangered Lesser Kestrel Falco naumanni. - Bird Study 48: 110-115.

Panuccio M., Agostini N., Massa B. (2004): Spring raptor migration over Ustica, southern Italy. - British Birds 97: $400-403$.

Panuccio M., Agostini N., Bogliani G. (20 i i): MountOlympus: a new raptor migration bottle-neck in northern Greece. In: Proceedings of the XVI Italian Ornithological Congress. - Cervia, Italy.

Panuccio M., Agostini N., Premuda G. (2012): Ecological barriers promote risk minimisation and social learning in migrating short-toed snake eagles. - Ethology Ecology \& Evolution 24 (1): 74-80.

Panuccio M., Agostini N., Barboutis C. (2013): Raptor migration in Greece: a review. - Avocetta 37: 1-7.

Perdeck A. (1977): The analysis of ringing data: pitfalls and prospects. - Die Vogelwarte 29: 33-44.

Premuda G., Mellone U. , Cocchi L. (2004): Osservazioni sulla modalità della migrazione primaverile dei rapaci a Capo d'Otranto. - Avocetta 28 (1): 33-36.

Premuda G., Gustin M., Pandolfi M., Sonet L., Cento M. (2008): Spring raptor migration along the Adriatic coast (Italy): a comparative study over three sites. - Avocetta 32: 13-20. 
Prugnolle F., Pilard P., Brun L., Tavecchia G. (2003): First-year and adult survival of the endangered Lesser Kestrel Falco naumanni in southern France: Local firstyear survival is higher in La Crau than in Spain with a high proportion of first-year birds returning to their natal area. - Bird Study 50 (1): 68-72.

QGIS Development Team. (2016): QGIS Geographic Information System. Open Source Geospatial Foundation Project. - [http://qgis.osgeo.org], 01/04/2016.

Rodriguez A., Negro J. J., Bustamante J., Fox J. W., Afanasyev V. (2009): Geolocators map the wintering grounds of threatened Lesser Kestrels in Africa. Diversity and Distributions 15 (6): 1010-1016.

Sammut M., Bonavia E. (2004). Autumn raptor migration over Buskett, Malta. - British Birds 97: 318-322.

Schindler S., Poirazidis K., Ruiz C., Scandolara C., Cárcamo B., Eastham C., Catsadorakis G. (2015): At the crossroads from Asia to Europe: spring migration of raptors and black storks in Dadia National Park (Greece). - Journal of Natural History 49: 285-300.

Serrano D., Tella J. L., Forero M. G., Donázar J. A. (200I): Factors affecting breeding dispersal in the facultatively colonial lesser kestrel: individual experience vs. conspecific cues. - Journal of Animal Ecology 70 (4): $568-578$.

Serrano D., Tella J. L., Donázar J. A., Pomarol M. (2003): Social and individual features affecting natal dispersal in the colonial lesser kestrel. - Ecology 84 (11): 3044-3054.

Strandberg R., KlaAssen R. H., Thorup K. (2009): Spatiotemporal distribution of migrating raptors: a comparison of ringing and satellite tracking. - Journal of Avian Biology 40 (5): 500-510.

Thorpe W., Holmes P. (1936): XXIX.-Notes on the Birds of Lakes Ochrid, Malik, and Prespa and adjacent parts of Yugoslavia, Albania, and Greece. - Ibis 78 (3): 557-580.

VAUGHAN R. (1960): Notes on autumn migration in Greece and Crete. - Ibis 102 (1): 87-92.

WicкнамH.,Chang W.(2009): ggplot2: An implementation of the Grammar of Graphics. - R package version 2.0.0.

Prispelo / Arrived: 14.4.2016

Sprejeto / Accepted: 5.7.2016 